\title{
The Effectiveness of the Application of The Kumon-Based English Learning Model to Improve Student Reading Ability
}

\author{
Oktariyani $^{1} *$ dan Oktariyana ${ }^{2}$ \\ ${ }^{1}$ Pendidikan Bahasa Inggris, Universitas Nahdlatul Ulama Lampung, Indonesia \\ ${ }^{2}$ Pendidikan Jasmani, Kesehatan dan Rekreasi, Universitas Nahdlatul Ulama Lampung \\ *oktariyani@unulampung.ac.id
}

\begin{abstract}
The purpose of this study was to determine the effectiveness of the application of Kumon-based English reading learning models compared with conventional methods of English reading skills of PGSD students and Management classes at Trilogy University 2018/2019 school year. This study uses a post-test-only control group design. The focus under study is the process and learning outcomes of students' reading comprehension (cognitive) results. This research uses documentation, observation, and test data collection techniques and analyzed with percentage descriptive techniques, and statistical tests. The ability of experimental class students viewed from the overall learning process is more capable $(73.3 \%)$ compared to the control class $(70 \%)$. Based on the percentage of students' post-test results, the control class obtained a percentage of $(86.9 \%)$ in the excellent category, while in the control class the percentage of post-test scores was $(68.33 \%)$ in the sufficient category. Thus the Kumon-based learning model is effective in improving students' reading ability in English both in terms of process and results compared to conventional methods.
\end{abstract}

Keywords: effectiveness, model, learning, kumon, reading.

Dikirim: 11 Juni 2020

Direvisi: 27 Juni 2020

Diterima: 29 Juni 2020

\section{Identitas Artikel:}

Oktariyani, O., \& Oktariyana, O. (2020). The Effectiveness of the Application of The KumonBased English Learning Model to Improve Student Reading Ability. Jurnal Ilmu Pendidikan (JIP) STKIP Kusuma Negara, 12(1), 16-24.

\section{INTRODUCTION}

\section{Background}

Reading activities for students is an activity that is difficult to make as a hobby or need. Students understand the importance of reading a lot (Megawati, 2017), but because reading is not considered a primary need as a student (Megawati, 2019), reading will be a tedious and time-consuming activity.

Likewise, with reading English language texts, in addition to not understanding the contents of these readings, students are also less motivated to understand English texts (Oktaviana, Harmayanthi \& Fitriani, 2019). This is of course due to the lack of vocabulary that is owned (Megawati, 2017).

Learning English vocabulary in Indonesia has started from kindergarten to high school. If it is calculated in a matter of years it is felt that enough vocabulary is understood by students.

But, based on the observations of researchers, there are still many students who are not fluent in pronouncing the A-Z alphabet in English. Especially to understand English texts, there are still many students who struggle. Also, there 
are some problems in the process of reading English texts namely the vocabulary is controlled so little that they lack understanding and they have difficulty remembering information after reading (Isti'anah, 2018).

The ability to read and understand English reading and depends on the level of student motivation (Oktaviana et al., 2019). This learning motivation is following what was explained in the study Milaningrum (2017) namely the comprehension reading ability of students who have high abilities is very significant compared to students who have low learning motivation. This means that high learning motivation is very influential in the ease of learning to read English and the ease of understanding English reading.

There are many methods and strategies employed by teachers and lecturers to increase student motivation and understanding in reading English texts (Megawati \& Fitriani, 2020). As conducted by an informal course institution in Indonesia, namely Kumon EFL. This institution applies the Kumon method for learning English. However, this method is not only applied to reading material but can be applied to general service company journal material, research conducted by Irmawati (2012).

Likewise, research conducted by Lin (2014) is about ERP (Extensive Reading Programming) strategies in improving students' linguistic abilities related to reading and promoting their motivation and attitudes towards reading.

The learning model for reading material is also widely practiced by researchers. Nofitria, Dawud \& Susanto (2017) examines the development of a model of learning to read critical text argumentation. The results of this study are models that have been developed that are feasible to be applied in critical reading learning.

Alsamadani (2011) research with the title The Effects of Dialogic Reading Strategy on EFL Young Learners' Reading Comprehension Skills. This research examines the effectiveness of learning to read English texts using dialogic reading strategies in elementary students. And the results of this study are that there are significant differences that indicate the superiority of groups of students who are given dialogic reading learning.

Also Pertiwi \& Sugiyanto (2007) researched the application of learning methods using constructive-active media, namely activities that are actively carried out that provide experience and knowledge, using paper media, markers, etc., which are used as simulations in the process understanding vocabulary and understanding word recognition in elementary school children.

Therefore in this study, the researchers conducted a trial of Kumon-based teaching material products to determine the effectiveness of students' abilities in reading English. The product developed in this research is reading teaching material in the form of reading learning books. The content of the material in the book is in the form of stories in English which are adjusted to the level of difficulty based on the level of student ability.

\section{Formulation of the Problem}

Based on the background of the research above, the researchers formulated the problem namely:

1. Are Kumon-based English learning products effectively used to improve students' reading skills? 
2. Does the Kumon method improve students' reading skills in terms of fluency, accuracy, intonation, pronunciation, and comprehension reading?

\section{Research Purposes}

The purpose of this study is to determine whether Kumon-based English learning models are effective in improving students' reading skills.

\section{RESEARCH METHODS}

The subjects in this study were students of the Trilogy University in the 2018/2019 even semester totaling 60 people coming from two different majors namely PGSD majors and Management Department students. Both majors were chosen by purposive sampling with the criteria for selecting the research sample

After that, the two groups of students were chosen to determine which group was the experimental group and which group was the control group randomly. And selected as the experimental group was 30 students majoring in PGSD while the control group was 30 students majoring in management.

The study used a posttest-only control group design. In this design there are two groups, each randomly chosen (R). The first group was given treatment (X) and the other group was not. This study does not use pretest data as an indicator of initial ability. The chart of this research is as follows.

\begin{tabular}{|c|c|c|}
\hline $\mathrm{R}$ & $\mathrm{X}$ & $\mathrm{O}_{1}$ \\
\hline $\mathrm{R}$ & & $\mathrm{O}_{2}$ \\
\hline
\end{tabular}

Picture 1. Char of Posttest-Only Control Group Design

The treatment in this study using the Kumon method as learning to read in the experimental group. The Kumon treatment method is used to improve cognitive aspects of reading including fluency, accuracy, pronunciation, intonation, and reading comprehension.

The Kumon Method will use teaching materials in the form of books. The material in the teaching material is English stories following the level of placement of students' abilities.

Data collection techniques used are observation, documentation, and tests. The test instrument was validated by SPSS testing and the validation of the contents of the reading learning material was validated by the learning expert, namely by the lecturer of the reading subject. This research uses descriptive analysis and statistical analysis. The application of learning products is declared effective if students already have cognitive aspects of reading, namely fluency, accuracy, pronunciation, intonation, and comprehension reading.

This data analysis is used to measure the effectiveness of the products produced at the trial stage in the experimental class and the control class. The data analyzed are:

a. Product development process data

b. Data on the product development process is disclosed descriptively in the steps of processing the English material reading process and results.

c. Data on product quality and quality 
d. Data regarding the level of quality and feasibility of the product were obtained through a validation test which was revealed descriptively and the product trial data through observation activities using the observation assessment sheet the steps in processing the observation assessment data are as follows:

1) Observation assessment sheet that has been filled in by the oblivion, the answer is complete. Then arranged according to the sequence of students.

2) Make data tabulation

3) Determine the percentage of each instrument,

4) To calculate the percentage of each instrument, researchers use a formula that refers to opinions (Sugiyono, 2011) as follows:

$$
P=\frac{f}{N} \times 100 \%
$$

Keterangan:

$f$ : The frequency that is being sought for the percentage

$N$ : Number of cases

$P$ : The percentage

5) Then the results will be adjusted to the criteria submitted Nurgiyantoro (2010) as

Table 1. Determination of Criteria with Percentage Calculations for Scale Four

\begin{tabular}{cccc}
\hline \multirow{2}{*}{ Interval Percentage of Mastery Level } & \multicolumn{3}{c}{$\begin{array}{c}\text { Conversion Value for } \\
\text { Four Scale }\end{array}$} \\
\cline { 2 - 3 } & $1-$ K & D-A & \\
\hline $86-100$ & 4 & $\mathrm{~A}$ & Very Good \\
$76-85$ & 3 & $\mathrm{~B}$ & Good \\
$56-75$ & 2 & $\mathrm{C}$ & Low \\
$10-55$ & 1 & $\mathrm{D}$ & Very Low \\
\hline
\end{tabular}

\section{RESULTS AND DISCUSSION}

The experimental research was carried out for 4 (four) meetings with details: 1 (one) introduction and observation 3 (three) treatments and 1 (one) post-test. Experimental research has 2 research classes, namely the experimental class, and the control class. Class control or comparison of the use of treatment with conventional learning methods. While the experimental class is a reading learning class using kumon-based learning methods and products. Learning reading English, both the experimental class and the control class is carried out by the researcher and one member of the researcher and assisted by two observers namely the lecturer supporting the reading subject and one elementary school teacher education student. The task of the observer is to observe all student activities during the learning process while providing an assessment of the student's initial abilities on the observation sheet provided by the researcher.

The percentage formula for student learning activities is as follows:

$$
N P=\frac{R}{S M} \times 100 \%
$$


Information:

$N P$ : Percent value sought or expected

$R$ : Raw Score obtained by respondents

$S M$ : Maximum Score obtained by respondents

100: Fixed Numbers

Table 2. Category Percentage of Respondent Activities

\begin{tabular}{cc}
\hline $85 \%-100 \%$ & Excellent \\
\hline $75 \%-84 \%$ & Very Good \\
\hline $65 \%-74 \%$ & Good \\
\hline $45 \%-64 \%$ & Low \\
\hline$\leq 44 \%$ & Very Low
\end{tabular}

Source: (Arikunto, 2007)

Data on students' initial reading abilities were obtained from observations of reading activities in the experimental class (PGSD) and the control class (Management). The results of student observations are presented in the following table.

Table 3: Percentage of Observation Result Values of Student Reading activities

\begin{tabular}{lcccccc}
\hline Ability & \multicolumn{3}{c}{ Experiment Class (PGSD) } & \multicolumn{4}{c}{ Control Class (Manajemn) } \\
\cline { 2 - 7 } & 1 & 2 & 3 & 1 & 2 & 3 \\
\hline Fluency & $87.50 \%$ & $100 \%$ & $87.50 \%$ & $75 \%$ & $75 \%$ & $87.50 \%$ \\
\hline Accuracy & $50 \%$ & $100 \%$ & $87.50 \%$ & $50 \%$ & $62.50 \%$ & $87.50 \%$ \\
\hline Pronunciation & $50 \%$ & $75 \%$ & $100 \%$ & $50 \%$ & $75 \%$ & $75 \%$ \\
\hline Intonation & $62.50 \%$ & $75 \%$ & $100 \%$ & $62.50 \%$ & $75 \%$ & $75 \%$ \\
\hline $\begin{array}{l}\text { Reading } \\
\text { comprehension }\end{array}$ & $62.50 \%$ & $62.50 \%$ & $87.50 \%$ & $62.50 \%$ & $62.50 \%$ & $75 \%$ \\
\hline $\begin{array}{l}\text { Average of Each } \\
\text { Meeting }\end{array}$ & $50 \%$ & $82.50 \%$ & $87.5 \%$ & $60 \%$ & $70 \%$ & $80 \%$ \\
\hline Overall Average & \multicolumn{7}{c}{$73,33 \%$} & & & $70 \%$ & \\
\hline
\end{tabular}

The overall average value of the experimental class was $73.33 \%$, which means it was superior to $3.33 \%$ than the control class which had an average value of $70 \%$ overall. Because the value of the reading activity of experimental class students is more than $70 \%$, learning is optimal and effective.

The results of the normality test of the significance value of more than 0.05 experimental class of 0.260 and the control class of 0.419 error rate of 5\%, then the data were declared normally distributed. Based on the results of the Levene Statistics test, it is known that the PGSD and Management classes as the control class and the experimental class have a significance value of 0.317 , greater than 0.05 , so it can be concluded that both classes based on the posttest values have the same or homogeneous conditions. Analysis results obtained $t_{\text {count }}=2.291$ $>t_{\text {table }}=1.994$ which means that there is an average difference between the experimental class and the control class. Because the t-test value is positive, the average value of the experimental class is higher than the control class.

The Effectiveness of the Kumon-based English Reading Learning Model on learning outcomes in terms of the process of implementing learning in the 
experimental class initially experienced a few obstacles, because students still felt ashamed. After being accustomed to this Kumon-based learning model students become more comfortable learning to read English.

At the initial meeting, students are still passive and difficult to read stories in the book because previously the student was not fluent in pronunciation and reading comprehension. This condition did not last long, because students felt more comfortable with the atmosphere of this Kumon-based learning, it can be seen from the development of the activeness of the experimental class that initially only $50 \%$ then increased to $82.50 \%$ and at the last meeting $87.50 \%$. The purpose of Kumon-based English reading learning is to open opportunities for students to learn based on their ability levels then learning is repeated. The faster the students read to understand the reading contents correctly, the faster the student switches to the next level of the story. Conversely, students who fail to complete the reading, understand the contents of the reading, and work on the questions must repeat similar activities until they are proficient then can proceed to the next level.

Learning in the control class uses conventional learning models (lectures, questions and answers, and assignments). Conventional learning does not motivate students to increase learning activities because students become listeners and teachers become the center of learning resources. Learning in the control class tends to make students sit quietly, fixated on reading material, and lecturer explanations. However, students are not active.

The ability of students increased at each meeting, but not significantly, starting from $60 \%$ at the first meeting, then increased to $70 \%$ at the second meeting where students began to understand the contents of the reading and ended at $80 \%$ at the last meeting where students began fluent reading English reading.

Ikmah, Margunani \& Yulianto (2012) The weaknesses of conventional learning models include, (1) students tend to feel bored because they are static in the same place during the learning process (2) students need a companion or guide in reading. Understanding and answering questions contained in the book, (3) students need a lecturer or assistant to be able to get an answer or an actual explanation, and (4) students need a lecturer or a companion to find out the evaluation results or the value of the questions that have been answered.

The Kumon-based learning model has the role of providing additional assignments for students with insufficient absorption as a repetition system for gaining complete knowledge. Because in reading, understanding, and doing assignments, students will look more prepared and proficient.

The activity at the end of learning is giving a post-test in the experimental class and the control class. The following Table 4 is the acquisition of students' post-test reading scores.

Based on the provision of the post test, it can be seen that there are differences in the average value between the experimental class and the control class. The experimental class gained an average value of $86.9 \%$ while the control class obtained an average value of $68.33 \%$. The average experimental class is higher than the control class due to the use of Kumon-based English reading learning models.

Chester (in Ikmah et al., 2012) explained that the activity was said to be effective if certain goals could eventually be achieved. The goal of learning 
English reading is achieving an optimal mastery level of $70 \%$ or more than the number of students can be completed. The percentage of completion for the experimental class at the final test reached $86.9 \%$, so it can be categorized as optimal learning and the Kumon-based learning method can be declared effective compared to the control class using conventional learning methods only reaching $68.33 \%$ with a good category.

Table 4. Acquisition of Student Reading Posttest Scores

\begin{tabular}{|c|c|c|c|c|}
\hline Responden & $\begin{array}{c}\text { Kelas } \\
\text { Experiment }\end{array}$ & Keterangan & $\begin{array}{c}\text { Kelas } \\
\text { Kontrol }\end{array}$ & Keterangan \\
\hline 1. & 80 & Baik & 70 & Cukup \\
\hline 2. & 86 & Baik Sekali & 75 & Cukup \\
\hline 3. & 85 & Baik & 73 & Cukup \\
\hline 4. & 90 & Baik Sekali & 72 & Cukup \\
\hline 5. & 93 & Baik Sekali & 60 & Cukup \\
\hline 6. & 70 & Cukup & 69 & Cukup \\
\hline 7. & 75 & Cukup & 74 & Cukup \\
\hline 8. & 85 & Baik & 60 & Cukup \\
\hline 9. & 80 & Baik & 64 & Cukup \\
\hline 10. & 95 & Baik Sekali & 76 & Baik \\
\hline 11. & 100 & Baik Sekali & 73 & Cukup \\
\hline 12. & 98 & Baik Sekali & 76 & Baik \\
\hline 13. & 100 & Baik Sekali & 71 & Cukup \\
\hline 14. & 76 & Baik & 74 & Cukup \\
\hline 15. & 90 & Baik Sekali & 74 & Cukup \\
\hline 16. & 86 & Baik Sekali & 77 & Baik \\
\hline 17. & 85 & Baik Sekali & 60 & Kurang \\
\hline 18. & 87 & Baik Sekali & 56 & Kurang \\
\hline 19. & 90 & Baik Sekali & 58 & Kurang \\
\hline 20. & 100 & Baik Sekali & 55 & Kurang \\
\hline 21. & 79 & Baik & 50 & Kurang \\
\hline 22. & 89 & Baik Sekali & 60 & Cukup \\
\hline 23. & 75 & Cukup & 65 & Cukup \\
\hline 24. & 80 & Baik & 62 & Cukup \\
\hline 25. & 83 & Baik & 61 & Cukup \\
\hline 26. & 81 & Baik & 67 & Cukup \\
\hline 27. & 80 & Baik & 75 & Cukup \\
\hline 28. & 100 & Baik Sekali & 76 & Baik \\
\hline 29. & 89 & Baik Sekali & 80 & Baik \\
\hline 30. & 100 & Baik Sekali & 87 & Baik Sekali \\
\hline Jumlah & \multicolumn{2}{|c|}{2607} & \multicolumn{2}{|c|}{2050} \\
\hline Persentase & \multicolumn{2}{|c|}{$86,9 \%$} & \multicolumn{2}{|c|}{$68.33 \%$} \\
\hline
\end{tabular}

Hypothesis testing can be seen in the final stage of the $t$-test that uses the average difference test (independent sample $t$-test). $t$-test results using the SPSS Independent Sample $t$-test showed that $\mathrm{H} 0$ was rejected because $t_{\text {count }}=2.291>t_{\text {table }}=1.994$, which means that there was an average difference that 
occurred in the experimental class and the control class. Besides that, from the ttest conducted it is known that the $\mathrm{t}$ value is positive so it can be concluded that the average value of the experimental class is higher when compared with the average value of the dick class.

Learning with Kumon-based English reading learning models is said to be effective because it can improve students' reading skills. After all, every student can work on the post-test questions given.

In general, the learning process using the Kumon-based English reading learning model that takes place in the learning process is going well. All stages of the research have been carried out properly as planned. The learning process has increased which can be seen from the process and the results obtained by students.

\section{CONCLUSION}

Learning outcomes in terms of the process seen from the ability of students showed the experiment class was more capable $(73.33 \%)$ than the control class $(70 \%)$. While in terms of results, statistical tests of the post-test results data indicate a difference in the average value, where the experimental class is higher (73) than the control class (70). The achievement level of completeness of the experimental class students in working on the post-test was considered optimal $(86.9 \%)$ capable students. Based on this explanation, Kumon-based English reading learning has proven to be more effective in improving students' reading skills compared to conventional methods.

\section{ACKNOWLEDGMENT}

The research team would like to express its deepest thanks to the Direktorat Riset dan Pengabdian Masyarakat, Direktorat Jenderal Penguatan Riset dan Pengembangan, Kementerian Riset, Teknologi, dan Pendidikan Tinggi who have funded this research from the Beginner Lecturer Research (Peneltian Dosen Pemula) grant for the implementation of the fiscal year 2020. May all those who have helped the research team get blessings from the Almighty.

\section{REFERENCES}

Alsamadani, H. A. (2011). The Effects of the 3-2-1 Reading Strategy on EFL Reading Comprehension. English Language Teaching, 4(3), 184-191.

Arikunto, S. (2007). Prosedur Penelitian Suatu Pendekatan Ilmiah. Jakarta: Rineka Cipta.

Ikmah, S. F., Margunani, M., \& Yulianto, A. (2012). Efektifitas Penerapan Metode Pembelajaran TAI (Team Assisted Individualization) Berbantuan Modul Pembelajaran Terhadap Hasil Belajar Ekonomi. Economic Education Analysis Journal, 1(1), 1-7.

Irmawati, N. D. (2012). Communicative Approach: An Alternative Method Used in Improving Students' Academic Reading Achievement. English Language Teaching, 5(7), 90-101.

Isti'anah, A. (2017). The effect of blended learning to the students' achievement in grammar class. Indonesian Journal of English Education, 4(1), 16-30. 
Lin, C. C. (2014). Learning English reading in a mobile-assisted extensive reading program. Computers \& Education, 78, 48-59.

Megawati, M. (2017). The Improving Students'reading Comprehension Through Grammar Translation Method. English Education: Journal of English Teaching and Research, 2(2), 95-108.

Megawati, M. (2019). The Effect Directed Reading Thinking Activity (DRTA) Strategy on Students' Reading Comprehension (An Experimental Study in Stkip Kusuma Negara Jakarta). Getsempena English Education Journal, 6(2), 172-181.

Megawati, M., \& Fitriani, D. (2020). The Effect SQ4R Technique On Students'reading Comprehension. Judika (Jurnal Pendidikan Unsika), 8(1), 19.

Milaningrum, E. (2017). Efektifitas Model Pembelajaran Kooperatif Round Table terhadap Keterampilan Reading Comprehension pada TOEFL Ditinjau dari Motivasi Belajar Mahasiswa Politeknik Negeri Balikpapan. JSHP: Jurnal Sosial Humaniora dan Pendidikan, 1(1), 21-27.

Nofitria, A., Dawud, D., \& Susanto, G. (2017). Pengembangan Model Pembelajaran Membaca Kritis Teks Argumentasi untuk Siswa Kelas X SMA/SMK. Jurnal Pendidikan: Teori, Penelitian, dan Pengembangan, 2(10), 1409-1415.

Nurgiyantoro, B. (2010). Penilaian Pembelajaran Sastra Berbasis Kompetensi. Yogyakarta: BPFE.

Oktaviana, N., Harmayanthi, V. Y., \& Fitriani, D. (2019). The Relationship Student Anxiety and Reading Comprehension of Recount Text. In Prosiding Seminar Nasional Pendidikan STKIP Kusuma Negara.

Pertiwi, P. P., \& Sugiyanto, S. (2007). Efektivitas Permainan Konstruktif-Aktif untuk Meningkatkan Kemampuan Membaca Siswa Kelas 2 Sekolah Dasar. Jurnal Psikologi, 34(2), 151-163.

Sugiyono. (2011). Metode Penelitian Kualitatif, Kuantitatif dan RD. Bandung: Alfabeta. 